Kravchynska Tetyana Serhiivna $\mathrm{PhD}$ (Pedagogical Sciences), Associate Professor, Doctoral Student of the Department of Public Administration and Project Management of the Educational and Scientific Institute of Management and Psychology of the State Institution of Higher Education "University of Education Management" of the National Academy of Pedagogical Sciences of Ukrain, Sichovykh Striltsiv St., 52-A, Kyiv 04053, tel.: (067) 797-85-62, e-mail: tatyana.krav@ukr.net, https://orcid.org/00000002-7521-3508

\title{
PUBLIC ADMINISTRATION OF THE PRESCHOOL EDUCATION SYSTEM IN UKRAINE : METHODOLOGICAL ASPECT
}

\begin{abstract}
The article considers the theoretical foundations of preschool education system management in Ukraine. Features and main components of state management of education are revealed. The mechanisms of state regulation of education are determined, among which: the system of means, levers, methods and incentives, by means of which the state regulates the functioning and development of education. The mechanisms of direct administration are not covered. Education is one of the branches that the state takes care of, creating conditions for its development. Public education management is a separate branch of public administration that provides a systematic impact on the educational sphere, based on laws and other regulations, and aimed at the development of this holistic system. Preschool education as the first link of lifelong learning realizes the child's right to receive such education that would correspond to his abilities, interests, inclinations, and take care of its maximum development immediately after birth. Currently, changes are needed in the system of preschool education in Ukraine, which are due to undergoing changes in the system and structure of general secondary education and the regularity of integration of national education into the European educational space. In particular, it is necessary to define conceptual long-term strategies for its further improvement and development. Preschool education and upbringing are carried out in the family and in preschool education institutions in cooperation with the family and are aimed at ensuring the physical and mental health of children, their comprehensive development, development of skills necessary for further education. The preschool is the first public center that a child attends. Education is a holistic, social system, for its study it is necessary to apply a systematic approach. Education is the very branch of life that needs constant renewal, and most importantly, education is the basic basis of the country's development in a developed society.
\end{abstract}


Keywords: public administration, components of public education management, mechanisms of state regulation of education, preschool education system.

Кравчинська Тетяна Сергіївна кандидатка педагогічних наук, доцентка, докторантка кафедри публічного управління i проектного менеджменту Навчально-наукового інституту менеджменту та психології Державного закладу вищої освіти «Університет менеджменту освіти» Національної академії педагогічних наук України, вул. Січових Стрільців, 52-А, м. Київ, 04053, тел.: (067) 797-85-62, e-mail: tatyana.krav@ukr.net, https://orcid.org/0000-0002-7521-3508

\section{ДЕРЖАВНЕ УПРАВЛІННЯ СИСТЕМОЮ ДОШКІЛЬНОЇ ОСВІТИ В УКРАЇНІ : МЕТОДОЛОГІЧНИЙ АСПЕКТ}

Анотація. У статті розглянуто теоретичні основи управління системою дошкільної освіти в Україні. Розкрито особливості та основні складові державного управління освітою. Визначено механізми державного регулювання освітою, серед яких: система засобів, важелів, методів і стимулів, за допомогою яких держава регулює функціонування і розвиток освіти, що виключає пряме адміністрування. Освіта є однією з галузей, якою опікується держава, створюючи умови для іiі розвитку. Державне управління освітою - це окрема галузь державного управління, яка забезпечує планомірний вплив на освітню сферу, що грунтується на законах та інших нормативних актах, i спрямована на розвиток цієї цілісної системи. Дошкільна ланка освіти як перша ланка неперервної освіти упродовж життя реалізує право дитини на здобуття такої освіти, яка б відповідала iii здібностям, інтересам, нахилам, дбала про іiі максимальний розвиток одразу після народження. Нині необхідні зміни в системі дошкільної освіти України, які зумовлені змінами в системі та структурі загальної середньої освіти й закономірністю інтеграції національної освіти в європейський освітній простір, зокрема варто визначити концептуальні довгострокові стратегії щодо іiі подальшого вдосконалення та розвитку. Дошкільна освіта i виховання здійснюються в сім’ї та в закладах дошкільної освіти у взаємодії з сім'єю і мають на меті забезпечення фізичного, психічного здоров'я дітей, їх всебічного розвитку, вироблення умінь, навичок, необхідних для подальшого навчання. Заклад дошкільної освіти є першим громадським осередком, до якого потрапляє дитина. Освіта $є$ системою цілісною, соціальною, для іiі вивчення необхідно застосовувати системний підхід. Освіта - це саме та галузь життя розвиненого суспільства, яка потребує постійного оновлення, а головне, освіта $є$ базовою основою розвитку країни.

Ключові слова: державне управління, складові державного управління 
освітою, механізми державного регулювання освітою, система дошкільної освіти.

Formulation of the problem. Issues in education, in particular the management of this area, have become particularly relevant during the reform of the state, as it requires a timely response to the challenges of the time, which requires the modernization of the education system and education management in particular. Education as the basis of social, political, economic, spiritual, cultural development of society is a state priority. As a state and public institution, it provides for the responsibility of the state and society for the state of its functioning. Education is the very branch of life of a developed society that needs constant renewal, and most importantly, education is the basic basis of the country's development.

The education system in Ukraine is a state instrument of realization of the constitutional right of citizens of Ukraine to education, namely - availability and free of charge of preschool, full general secondary, vocational, higher education in state and municipal educational institutions, development of preschool, full general secondary, out-of-school, vocational, higher and postgraduate education; various forms of education; providing state scholarships and benefits to pupils and students (Article 53 of the Constitution of Ukraine) [1].

World communities have long been investing significant resources in the development of preschool education, realizing that it is at an early age that the foundation is laid for the further success of the child, his harmonious development. Thus, in 2010, under the auspices of UNESCO, the World Conference on Education, Upbringing and Development of Early and Preschool Children was held for the first time, which was attended by a thousand participants from 193 countries. The conference participants noted that the education, training and upbringing of preschool children is the first fundamental step towards "creating the wealth of the nation" [2].

Preschool education as the first link of lifelong learning realizes the child's right to receive such education that would correspond to his abilities, interests, inclinations, and take care of its maximum development immediately after birth. At present, changes are needed in the system of preschool education in Ukraine, which are due to changes in the system and structure of general secondary education and the regularity of integration of national education into the European educational space. The modernization of preschool education is associated with European and global trends and challenges, the growing attention of the international community to this level of education.

Analysis of recent research and publications. Analysis of domestic and foreign scientific sources shows that there are many different approaches to the essence of management. Today there are only some developments in the management of the preschool education system, but the attempt to rely on the provisions of the Western theory of management, does not always have a positive effect on domestic theory and 
practice of management. Such attempts do not lead to the formation of a general theory of management of preschool education, which should not only be based on the laws of management, but also take into account the peculiarities of the management of preschool education of different types. Preschool institutions have their own specific characteristics both in activity and in management, inherent only in these types of educational institutions. All of them should be taken into account in the work of the governing bodies of the preschool education system at all levels.

Scientists I. Bekh, I. Vakarchuk, I. Zyazyun, V. Kremen, V. Luhovyi, T. Lukina, V. Oliynyk, O. Pometun, M. Stepko considered the educational sphere of Ukraine as an object of public administration and provide full and systematized information about the state and dynamics of education, its achievements, prospects and problems of development. Preschoolers O. Dolynna, L. Zdanevych, N. Makovetska, O. Pastyuk, L. Pisotska and others study preschool education as a subsystem of education. And the problems of the essence and content of the methodology of public administration are considered in the works of scientists B. Gurne, B. Lazarev, G. Wright, E. Toffler, F. Fukuyama, P. Schroeder and others.

The purpose of the article is to reveal the peculiarity of the state management of preschool education as the first link of lifelong learning.

Research methods. A set of methods was used for the study, including theoretical: analysis, synthesis, comparison, generalization to study the scientific literature to compare the positions of scientists on methods of education management.

Presenting main material. Ukraine inherited a well-developed network of preschools, most of which were departmental. In 1990, there were 2,428,000 children in 24,5 thousand preschool institutions. According to the State Statistics Service of Ukraine, in 2019 there were about 15 thousand preschool institutions that attended 1230 thousand children (excluding the temporarily occupied territory of the Autonomous Republic of Crimea, Sevastopol and the temporarily occupied territories in Donetsk and Luhansk regions) [3]. During the period from 1990 to 2019, the number of preschool institutions in Ukraine decreased, and accordingly the number of preschool children covered by these institutions decreased. The changes that have taken place during the years of Ukraine's independence in the functioning of the network of preschool education institutions cannot be considered positive.

The system of preschool education, on the one hand, must flexibly and dynamically adapt to socio-economic changes in society, on the other - in its psychological and pedagogical basis not to succumb to the situation, because any education system must grow from educational systems that historically to be futureoriented, as applicants for educational institutions of this system will live and work in significantly new conditions. Education as a broad social phenomenon goes far beyond the traditional issues of teaching. As an important area of forming the personality of the 
development of society, it should become the object of public administration.

Preschool education and upbringing are carried out in the family and in preschool education institutions in cooperation with the family and are aimed at ensuring the physical and mental health of children, their comprehensive development, development of skills necessary for further education. The preschool is the first public center that a child attends.

The network of pre-school institutions has significantly decreased, which has affected the social protection of children, especially from low-income and single-parent families, children living in rural areas. This is due to various reasons: deteriorating demographic situation, sharp decline in family welfare against the background of deteriorating economic situation associated with the COVID-19 pandemic, which makes it impossible to pay for a child's attendance at preschool, reorganization or suspension of preschool education. In modern conditions, special attention needs family upbringing, family education, preparation of parents for this.

It should be noted that the development of educational policy in Ukraine is significantly influenced by national and historical traditions. Because of this, the educational system, principles and the basis of its functioning in our country often differ from those generally accepted in the world community, and domestic educational legislation for the same reason is sometimes contradictory. State policy in education is characterized by continuous and consistent development and implementation of measures to reform the education sector. Transformations are aimed, firstly, at the formation of an integrated national education system of a sovereign, independent Ukrainian state, secondly, at the adaptation of the education system to democratic, legal, market relations in society, and thirdly, at its integration into the international education system. globalization of the world.

The scientific theory of public administration has expanded significantly in recent years, borrowing and combining ideas from economics and philosophy, management theory and sociology, organized by means of systems thinking. However, the formation of the methodology of public administration in general, as well as the methodology of education management, has not yet been completed and the theoretical and methodological foundations and conceptual provisions of public administration of education need to be clarified.

T. Sidoruk notes that the methodology of public administration is a system of ways to organize and implement cognitive and practical activities in public administration, which includes a subsystem of research methods (concepts, principles, approaches, methods, norms, paradigms, etc.) in public administration and a subsystem of methods (principles, approaches, methods, techniques, procedures, technologies, etc.) of public administration, which is closely related to theoretical knowledge, which is the basis of its development and at the same time develop themselves with the help of new 
methodological tools [4].

The dictionary-handbook of public administration gives us the definition that the process of public administration is a conscious and purposeful consistent activity associated with the implementation of state powers by public administration, resulting in changes in social conditions, events and phenomena. The process of public administration is aimed at implementing public strategy and policy and it is the main way to implement subject-object relations at the state level, where the subject of public administration is a system of public power in the form of specially formed bodies, among which are distributed certain functions of public administration, and the object of public administration is the whole society [5].

In a broad sense, management as a complex socio-economic process means the impact on processes, objects, systems in order to maintain their sustainability or transfer from one state to another in accordance with the goals. Public administration of education is a special type of professional activity aimed at the education system in order to ensure its viability, dynamic development due to changing circumstances. The essence of education management is purposeful activities to create socio-prognostic, organizational, legal, personnel, pedagogical, material and financial and other conditions necessary for the optimal functioning and development of the industry, the realization of its purpose, the transition to a qualitatively new state [6].

T. Lukina's researches are important for determination of theoretical and methodological bases of the state management of education. Analyzing different approaches to interpreting the content of the mechanism of public administration, defining the list of principles and functions of public administration, T. Lukina emphasizes the lack of thorough research on the structure and features of the mechanism of public administration of social systems, including education. The researcher proposes to understand the mechanism of public quality management of education as a certain structure of the public quality management system of general secondary education, indicating the set of processes, patterns, which make up the management itself as a social and socio-political phenomenon. This mechanism is based on the state-public form of government and exerts managerial influence on various factors on which the quality of education directly or indirectly depends both as a result, the educational process and the system. The mechanism of state quality management of general secondary education is presented as a dynamic entity that can be exposed to external factors. In his research, T. Lukina substantiates the feasibility of assessing the effectiveness of public quality management of education in terms of its social effectiveness [7].

Management in education is considered as a subsystem of social management, which signifies the impact on society in order to organize it, preserve the qualities, specifics, improvement and development. According to the definition of 
A. L. Sventsytsky, social management - purposeful, systematic and systematic informational impact of the subject of management on its object, taking into account the changes taking place in it [8]. Accordingly, the management of education is defined as the purposeful influence of the subjects of management at different levels (state, regional, local) on all levels of education to ensure and further development of the social organism and culture of society.

Researcher S. V. Krysiuk notes that education is one of the branches that the state takes care of, creating conditions for its development. Therefore, public administration of education - a certain activity of public authorities, which has an executive and administrative nature, is the organizational impact on public relations in the field of education through the use of public authority and includes targeted development, adoption and implementation of organizing, regulatory and coordinating decisions, influencing the educational sphere [6]. Thus, public administration of education is a separate branch of public administration, which provides a systematic impact on the educational sphere, based on laws and other regulations, and aimed at the development of this holistic system, and the mechanisms of public administration - are tools, levers, incentives, methods by which the subjects of education management influence the educational sphere in order to achieve the set goals.

Peculiarity of state management of education (according to S. V. Krysiuk):

1. Has an authoritarian character, extends to the entire education system, is implemented by a hierarchically structured apparatus, endowed with certain powers through numerous managerial influences, the nature and typology of which are determined by the specifics of the objects.

2. Public administration is a process of realization of the state power, its external materialized expression which is carried out as purposeful influence on system of education or on its separate links on the basis of knowledge and use of objective laws and tendencies inherent in system in the interests of achievement of the set purpose or a certain set of goals, ensuring its optimal functioning and development.

3. Public administration operates systematically, combines the functioning of two complex structures - the state apparatus of education management and public institutions of society and the public [6].

And the main qualities that characterize the state management of education are:

- the presence of governing bodies endowed with certain powers and whose activities are aimed at certain objects of the educational sector;

- existence of managerial ties, relations and organization of both subjects and objects of management;

- availability of management functions related to ensuring the existence and development of the industry. 
Public administration of education is a system of public administration activities, the components of which are strategic management, government regulation and administrative management. Strategic management of education - the theoretical activities of senior management of education, central education authorities, aimed at developing a strategy for the development of the education sector, its individual subsystems. In the process of development and improvement, the system of public administration grows into a system of state regulation. State regulation of education is a purposeful influence on the education system, which is carried out mainly through the adoption of legislation, norms, regulation, improvement of general rules and norms of behavior that prevent negative phenomena in the educational environment. The mechanisms of state regulation of education are a system of means, levers, methods and incentives by which the state regulates the functioning and development of education, which excludes direct administration. Administrative management of education is the activity of specially created governing bodies, which has an executive and administrative nature and consists in organizing, regulating and coordinating influences on the education system through the use of state powers. The main mechanism of administrative management is specially created governing bodies, endowed with power, which perform executive and administrative functions [6].

And the functions of state management of education - are the types of power, goalsetting, regulatory influences (actions) of the state, its bodies on the objects of education management, carried out in accordance with the law, using special methods to implement state tasks. They are objective in nature, closely related to the social functions of the state. The functions of education management are performed by any subject of management in the process of managing any object [9]. Subjects of management are a set of specially created bodies (state, public, self-government), their subdivisions, officials who perform management functions. Objects of education management are the education system, education management bodies, their subdivisions, officials, educational institutions, industrial enterprises that are under the organizing, regulatory and coordinating influence of the state.

Researcher L. Parashchenko, studying the mechanisms of public administration of general secondary education, notes that public administration mechanisms are a category of government that reflects difficult to unambiguously identify parts of the public administration system, which include management goals, management resources, social and organizational potential, the relationship of different controls, by means of which influence in subject-object interactions is carried out. Mechanisms of public administration are built on the principle of "motryka", ie each of the mechanisms includes all other mechanisms. They should also be considered as a systemconfigurator, stacked on different dimensions. And the mechanism of public management of general secondary education can be defined as the multiplication of 
institutional mechanisms of public administration, which in the form of organizational and regulated interaction (strategic game) between the center and management facilities provide development of teaching staff, content, learning environment, evaluation, goal setting (educational policy) and management/financing of general secondary education, and procedural mechanisms of organizational, legal, economic, political nature, the priority of which is determined by the functions of general secondary education, and their effectiveness is determined by the level of human capital of participants in the educational process $[10 ; 11]$.

In the "Encyclopedic Dictionary of Public Administration" the concept of mechanisms of public administration is defined in the broadest sense as ways to resolve contradictions of a phenomenon or process in public administration, consistent implementation of actions based on fundamental principles, goal orientation, functional activity using appropriate forms and management methods [12].

S. Krysiuk considers the mechanisms of public administration to be the main categories of public administration of education, which include, first of all, the category of the state as a reflection of the main instrument of the political system of society that manages the education system. According to the researcher, state power influences the processes in the educational environment with the help of specially formed bodies and institutions, which are part of a single mechanism of state power. S. Krysiuk uses the mechanisms of public administration to determine the means, levers, incentives, methods by which the subjects of education management influence the educational sphere in order to achieve certain goals. By the nature of the impact, the scientist identifies political, organizational, legal, economic, social mechanisms on the basis of which the organizational and administrative, administrative and executive activities of education authorities [6].

Mechanisms of public administration, as noted by V. Malinovsky [13], form a set of tools for organizing management processes and ways to influence the development of managed facilities using appropriate management methods aimed at achieving the goals of public administration.

Domestic scientists N. Nizhnik and A. Mashkov, substantiating the mechanisms of public administration, define them as a component of the management system, providing an impact on the factors, on the state of which the result of the activity of the administrative object depends. Management factors for the organization can be internal (when it comes to the management mechanism of the organization) or external (then talk about the mechanism of interaction with other organizations). The management mechanism, in their opinion, covers the objectives of management, the elements of the object and their relationships that are affected, actions in the interests of achieving goals, methods of influence, material and financial resources of management, social and organizational potential. The real management mechanism is always specific, because it 
is aimed at achieving specific goals by influencing specific factors, and this impact is managed through the use of specific resources [14].

The functioning of public administration mechanisms is based on certain principles, according to which the organizational-administrative and administrativeexecutive activities of education management bodies are carried out. It should be noted here that the definition of "organizational and functional structure of public education management" is of great methodological importance, which provides for the establishment of clear relationships between individual governments, units of specific bodies, the distribution of powers, duties and responsibilities [6]. Thus, the organizational and functional structure of state education management is a system of state power, state institutions, organizations, their functions, the relevant organizational relationships sovereign-managerial inflow on education in order to ensure its functioning and development.

L. Prykhodchenko, studying the mechanisms of public administration, identifies two approaches to interpreting the content of this category, which he calls "structuralorganizational" (as a set of certain constituent elements that create the organizational component of certain phenomena, processes) and "structural-functional" (with emphasis not only on the organizational basis of its construction, but also on the dynamics, the actual functioning) [15].

Thus, the diversity of types of management generates a variety of types of management mechanisms. This conclusion is important for studying and determining the types of mechanisms of public administration of preschool education that are inherent in the field of education, with which the leaders of different hierarchical levels are most familiar and implement in their professional activities and which are the least studied in public administration.

Based on the above, we can conclude that public administration of preschool education is a branch of public administration that provides a systematic impact on preschool education, based on laws and other regulations, and aimed at developing this holistic system. The centralized system of education management contributes to the creation of educational standards, preservation and strengthening of the sense of cultural community of the population, but strengthens the authoritarian tendencies of education management, ignores or underestimates the peculiarities of regional specifics and so on. The decentralized model of education management opens a wide space for the development of local initiative, allowing the development of education taking into account local characteristics.

Conclusion. Thus, public administration is an important type of human activity that ensures the preservation and development of society. The quality of public administration depends on the successful development of almost all social subsystems and structures, the success of society, the realization of the interests and capabilities of 
people, their security and future. Public administration of education develops in accordance with the development of society and the state. It is influenced by a number of trends and factors of social development. The leading role among them is played by both the processes of the external environment (globalization and its challenges, the transition to the information society, democratization and emancipation of man) and internal factors in the development of management as a sphere of human activity. Among them are social, economic, political, value and mental prerequisites.

Preschool education is an integral part and the first level in the education system the starting platform for personal development of the child. For preschool education for the near future the most important are the balance of its network in accordance with the needs of different types of preschool education, protection of this system, bringing it into line with international standards, development of software and methodological support for the basic component of preschool education as a mandatory level of education, which will allow to make the most of the opportunities of early age in the interests of education and development of children.

Thus, in domestic theory and practice there is no single scientific approach to public administration of preschool education, they are at the level of scientific research, so there is room for scientific research and discussion.

\section{References:}

1. Konstytutsiya Ukrayiny [Constitution of Ukraine]. Retrieved from https://u.to/wjwbGg [in Ukrainian].

2. Kremen', V. (2016). Natsional'na dopovid' pro stan i perspektyvy rozvytku osvity v Ukrayini [National report on the state and prospects of education development in Ukraine]. Za zah. red. V. H. Kremenya. Kyyiv. Pedahohichna dumka. 448 s., 44-50 [in Ukrainian].

3. Derzhavna sluzhba statystyky Ukrayiny [State Statistics Service of Ukraine]. Retrieved from http://www.ukrstat.gov.ua/ [in Ukrainian].

4. Sydorchuk, T.V. (2013). Metodolohiya nauky pro derzhavne upravlinnya v konteksti rozvytku suchasnoyi nauky [Methodology of public administration science in the context of modern science development]. Investytsiyi: praktyka ta dosvid. 11, 130-132 [in Ukrainian].

5. Bakumenko, V.D., Beznosenko, D.O., Varzar, I.M., Knyazyev, V.M., Kravchenko, S.O., Shtyka, L.H. (2002). Derzhavne upravlinnya: Slovn.-dovid [Public administration: Slovn.-dovid]. Uklad. : V. D. Bakumenko (ker. tvorchoho kol.), D. O. Beznosenko, I. M. Varzar, V. M. Knyazyev, S. O. Kravchenko, L. H. Shtyka. Zah. red. V. M. Knyazyeva, V. D. Bakumenka. K. Vyd-vo UADU. 228 s. [in Ukrainian].

6. Krysyuk, S.V. (2009). Derzhavne upravlinnya osvitoyu : navch. posib. dlya slukhachiv, asp., doktorantiv spets. «Derzhavne upravlinnya osvitoyu» [State management of education: textbook. way. for students, graduate students, doctoral students special. "State Management of Education"]. K. NADU. 220 s. [in Ukrainian].

7. Lukina, T.O. (2004). Derzhavne upravlinnya yakistyu zahal'noyi seredn'oyi osvity v Ukrayini : monohrafiya [State quality management of general secondary education in Ukraine: monograph]. K. Vid-vo NADU. 292 s. [in Ukrainian]. 
8. Sventsitskiy, A.L. (1986). Sotsial'naya psikhologiya upravleniya [Social psychology of management]. Pod red. Ye. S. Kuz'mina. L. Izd-vo LGU. 176 s. [in Russian].

9. Protasova, N.H., Krysyuk, S.V., Lukina, T.O. ta in. (2012). Derzhavne upravlinnya u sferi osvity : konspekt lektsiy $\mathrm{z}$ dystsyplin normatyvnoyi chastyny mahisters'koyi prohramy za spetsial'nistyu «Derzhavne upravlinnya u sferi osvity» [Public administration in the field of education: a synopsis of lectures on the disciplines of the normative part of the master's program in the specialty "Public administration in the field of education"]. Za zah. red. N. H. Protasovoyi. K. NADU. 60 s. [in Ukrainian].

10. Parashchenko, L. (2012). Mekhanizmy derzhavnoho upravlinnya zahal'noyu seredn'oyu osvitoyu v konteksti natsional'noyi stratehiyi rozvytku osvity [Mechanisms of public administration of general secondary education in the context of the national strategy of education development]. Elektronnyy zhurnal «Derzhavne upravlinnya: udoskonalennya ta rozvytok». № 1. Retrieved from http://www.dy.nayka.com.ua/?op=1\&z=382 [in Ukrainian].

11. Parashchenko, L.I. (2011). Derzhavne upravlinnya rozvytkom zahal'noyi seredn'oyi osvity v Ukrayini: metodolohiyi, stratehiyi, mekhanizmy: monohrafiya [State management of general secondary education development in Ukraine: methodologies, strategies, mechanisms: monograph]. K. Vydavnytstvo Mayster knyh. 536 s. [in Ukrainian].

12. Surmin, YU.P., Bakumenko, V.D., Mykhnenko, A.M. ta in. (2010). Entsyklopedychnyy slovnyk $\mathrm{z}$ derzhavnoho upravlinnya [Encyclopedic dictionary of public administration]. Za red. YU. V. Kovbasyuka, V. P. Troshchyns'koho, YU. P. Surmina. K. NADU. 820 s. [in Ukrainian].

13. Malynovs'kyy, V.YA. (2003). Derzhavne upravlinnya : navch. posib. [Public administration: textbook]. Vyd. 2-he, dopov. ta pererob. K. Atika. 576 s. [in Ukrainian].

14. Nyzhnyk, N.R., Mashkov, O.A. (1998). Systemnyy pidkhid v orhanizatsiyi derzhavnoho upravlinnya : navch. posib. [System approach in the organization of public administration: textbook]. K. Vid-vo UADU. 160 s. [in Ukrainian].

15. Prykhodchenko, L. (2008). Sutnist' ponyat' mekhanizmiv derzhavy, derzhavnoho upravlinnya ta derzhavnoho rehulyuvannya [The essence of the concepts of mechanisms of state, public administration and state regulation]. Aktual'ni problemy derzhavnoho upravlinnya: zb. nauk. pr. Odes. rehion. in-tu derzh. upr. Odesa. ORIDU NADU. Vyp. 3 (35). S. 269-274. [in Ukrainian].

\section{Jimepamypa:}

1. Конституція України. URL : https://u.to/wjwbGg

2. Національна доповідь про стан і перспективи розвитку освіти в Україні. За заг. ред. В. Г. Кременя. Київ. Педагогічна думка. 2016. 448 с. С. 44-50.

3. Державна служба статистики України. URL : http://www.ukrstat.gov.ua/

4. Сидорчук Т. В. Методологія науки про державне управління в контексті розвитку сучасної науки. Інвестииії: практика та досвід. 2013. № 11. С. 130-132.

5. Державне управління: Словн.-довід. Уклад.: В. Д. Бакуменко (кер. творчого кол.), Д. О. Безносенко, І. М. Варзар, В. М. Князєв, С. О. Кравченко, . Г. Штика. Заг. ред. В. М. Князєва, В. Д. Бакуменка. К. Вид-во УАДУ. 2002. 228 с.

6. Крисюк С. В. Державне управління освітою: навч. посіб. для слухачів, асп., докторантів спец. «Державне управління освітою». К. НАДУ. 2009. 220 с.

7. Лукіна Т. О. Державне управління якістю загальної середньої освіти в Україні : монографія. К. Вид-во НАДУ. 2004. 292 с.

8. Свенцицкий А. Л. Социальная психология управления. Под ред. Е. С. Кузьмина. Л. Издво ЛГУ. 1986. 176 с. 
9. Протасова Н. Г., Крисюк С. В., Лукіна Т. О. та ін. Державне управління у сфері освіти : конспект лекцій з дисциплін нормативної частини магістерської програми за спеціальністю «Державне управління у сфері освіти». За заг. ред. Н. Г. Протасової. К. НАДУ. 2012. 60 с.

10. Паращенко Л. Механізми державного управління загальною середньою освітою в контексті національної стратегії розвитку освіти. Електронний журнал «Державне управління: удосконалення та розвиток». № 1. 2012. URL : http://www.dy.nayka.com.ua/?op=1\&z=382

11. Паращенко Л. І. Державне управління розвитком загальної середньої освіти в Украӥні: методології, стратегіï, механізми : монографія. К. Видавництво Майстер книг. 2011. 536 с.

12. Сурмін Ю. П., Бакуменко В. Д., Михненко А. М. та ін. Енцииклопедичний словник 3 державного управління. За ред. Ю.В.Ковбасюка, В. П. Трощинського, Ю. П. Сурміна. К. НАДУ. 2010. 820 с.

13. Малиновський В. Я. Державне управління : навч. посіб. Вид. 2-ге, допов. та перероб. К. Атіка. 2003. 576 с.

14. Нижник Н. Р., Машков О. А. Системний підхід в організації державного управління : навч. посіб. К. Вид-во УАДУ. 1998. 160 с.

15. Приходченко Л. Сутність понять механізмів держави, державного управління та державного регулювання. Актуальні проблеми державного управління: зб. наук. пр. Одес. регіон. ін-ту держ. упр. Одеса. ОРІДУ НАДУ. 2008. Вип. 3 (35). С. 269-274. 